\title{
Construindo e aprendendo com o trabalho
}

\author{
Working and learning in the process
}

\author{
Anselmo Gomes de OLIVEIRA; \\ Dâmaris SILVEIRA \\ Editores-Chefe
}

Ao publicarmos o último número do volume 29, out-dez 2017, estamos encerrando mais um ano de atividades do periódico Infarma - Ciências Farmacêutica. E gostaríamos de registrar nossos agradecimentos a todos - autores, revisores, editores associados e membros do corpo editorial - que contribuíram decisivamente para que esse trabalho se concretizasse durante o ano. O trabalho independente de todos, em cada etapa da preparação de cada um dos fascículos foi fundamental para que nosso periódico pudesse levar até os leitores os diversos temas, de relevância, que foram veiculados neste ano. Das ferramentas da qualidade até os cuidados farmacêuticos, passando pela Farmacognosia, Assistência Farmacêutica, assuntos regulatórios e outros, os temas abordados refletiram o largo escopo das Ciências Farmacêuticas e as diversas áreas de atuação.

Gostaríamos de ressaltar que a responsabilidade ética dos editores do periódico levou à introdução da figura dos Editores associados, representantes das regiões Norte, Nordeste, Centro-Oeste, Sul e Sudeste, além da renovação do corpo editorial, que conta com representantes do Brasil e do exterior em suas áreas de atuação relacionadas às Ciências Farmacêuticas e que colaboram, de forma voluntária, para o êxito de Infarma - Ciências Farmacêuticas. Tal reestruturação foi fundamental para tornar a comunicação entre editores, revisores e autores muito mais eficiente, e tem refletido em cada número publicado. Evidentemente foi um ano de trabalho intenso, mas compensador, pela significância de Infarma - Ciências Farmacêuticas para a comunidade científica da área.

Nos números 1-4, do volume 29 , foram publicados 35 artigos originais, 8 de revisão e 2 notas técnicas. Foi possível, neste volume 29, além dos quatro números regulares, publicar três suplementos, referentes aos resumos de eventos importantes na área das Ciências Farmacêuticas, ou seja, v.29, eSupl. 1, 2017, p.1-286 -
"Resumos do XII Congresso Mundial de Farmacêuticos de Língua Portuguesa; V Simpósio de Plantas Medicinais e Fitoterápicos no Sistema Público de Saúde; Congresso Internacional de Fitoterapia; I Congresso Brasileiro de Farmácia Estética e I Simpósio Farmacêutico de Nutracêuticos"; v29, eSup2.a2017. p.287-320 - "Resumos do XII Congresso Mundial de Farmacêuticos de Língua Portuguesa; V Simpósio de Plantas Medicinais e Fitoterápicos no Sistema Público de Saúde; Congresso Internacional de Fitoterapia; I Congresso Brasileiro de Farmácia Estética e I Simpósio Farmacêutico de Nutracêuticos (Parte 2)"; e v29.eSup13.a2017.p.321-691, Resumos do VIII Simpósio Iberoamericano de Plantas Medicinais e do III Simpósio Iberoamericano de Investigação em Câncer. Esses diversos suplementos mostram o reconhecimento da comunidade científica quanto à importância do periódico no cenário das Ciências Farmacêuticas.

Embora o sistema de avaliação por pares adotado no periódico para a decisão final dos editores pela publicação dos artigos seja um processo rigoroso e o índice de rejeição da revista seja bastante alto, em 2017 houve uma consolidação da demanda de submissões surpreendente, o que tem permitido cumprir rigorosamente o cronograma das publicações dos números, nos prazos adequados. As colaborações dos autores, embora de certa forma, guardem as vocações regionais, no contexto global representam os interesses principalmente dos pesquisadores na área das Ciências Farmacêuticas.

Com a convicção de que nosso periódico ainda continuará em crescente evolução, merecendo a confiança depositada pelos leitores e autores, os editores de Infarma - Ciências Farmacêuticas e o Conselho Federal de Farmácia agradecem a todos os seus colaboradores e convidam para a leitura, desse último número de 2017. no site http://revistas.cff.org.br/?journal=infarma 